\title{
NOTES
}

\section{AN ANTITRUST ANALYSIS OF COLLEGE EARLY ADMISSION PROGRAMS}

Adam L. Henry

\section{INTRODUCTION}

College admissions at the level of elite colleges and universities would seem, to the uninitiated, to offer a model of the competitive market that antitrust law endeavors to promote and maintain. Notwithstanding the significant branding power of a handful of truly elite colleges, the college market exhibits many of the paradigmatic competitive market's hallmark features, including substantial numbers of both producers and consumers of the educational product, and seemingly unhindered information on the parts of both parties. ${ }^{1}$ Indeed, there can be little doubt that the system promotes sometimes-fierce competition: not only among applicants for elite colleges, but also among colleges for elite applicants. Such competition drives colleges to make themselves more attractive in two ways: by reducing prices through scholarships, grants, research stipends, and the like, and by improving their product through inducements like honors designations and programs. In either form, this competition redounds to the economic benefit of admitted students.

But, despite its competitive appearances, the college admissions market is not without its anticompetitive elements. Colleges collude in various ways to reduce the price wars for top applicants that would otherwise be inevitable in a truly free market and that would work to deplete their substantial

1. See Andrew I. Gavil et al., Antitrust law in Perspective: Cases, Concepts and Problems in Competition Policy 39 (2002). 
endowments. In 1958, the Massachusetts Institute of Technology ("MIT") and the eight colleges comprising the Ivy League formed the Ivy Overlap Group to prohibit merit-based financial aid and to establish a formula for need-based aid that produced comparable aid packages for common admits. ${ }^{2}$ A district court classified the agreement as horizontal price-fixing in violation of Section 1 of the Sherman Antitrust Act, ${ }^{3}$ which famously reads: "Every contract, combination in the form of trust or otherwise, or conspiracy, in restraint of trade or commerce ... is declared to be illegal." " Of the nine defendants, only MIT declined to sign a consent decree, ${ }^{5}$ and, after its appeal to the Third Circuit produced disagreement only as to the standard of review, it settled with the Antitrust Division of the Justice Department. ${ }^{6}$ Following the consent decrees and settlement in that case, United States v. Brown University, ${ }^{7}$ colleges instituted their own formulas for need-based financial aid, producing aid packages of varying sizes for common admits. More recently, 28 needblind private colleges have pledged themselves to use of a common methodology, ${ }^{8}$ taking advantage of a relaxation in rules afforded by Section 568 of Public Law 103-382. . The "568 Presidents' Working Group" has, however, done away with price fixing at the level of the common admit, a feature of the Ivy Overlap system found especially inimical to competitive principles. $^{10}$

More inimically still, the vast majority of elite institutions now restrain the commerce of college admissions through various early admissions programs that offer to applicants early admissions decisions as a quid pro quo for their early expressions of interest. ${ }^{11}$ These programs come in an increasing number of forms, but the principal varieties are two: Early Decision ("ED") and Single-Choice Early Action ("EA"). ${ }^{12}$ Each restricts the applicant to application to a single college in the early round, but whereas ED mandates

\footnotetext{
2. United States v. Brown Univ., 5 F.3d 658, 662 (3d Cir. 1993).

3. See United States v. Brown Univ., 805 F. Supp. 288, 301 (E.D. Pa. 1992).

4. 15 U.S.C. $\S 1$ (2000).

5. Brown Univ., 5 F.3d at 664.

6. Christopher Avery et al., The Early Admissions Game: Joining The Elite 33 (2003).

7. Brown Univ., 5 F.3d at 664.

8. Rachel Osterman, Aid Plays Growing Role in Recruitment, The Dartmouth, May 6, 2002, available at http://www.thedartmouth.com/index.php?date=2002-05-6 (last visited Feb. 21, 2005).

9. Improving America's Schools Act of 1994, § 568, 20 U.S.C. 6301 (2000); Osterman, supra note 8 , at 3 .

10. Osterman, supra note 8 , at 3 .

11. "Of the 281 private institutions ranked as the 'Best National Universities' and 'Best Liberal Arts Colleges' by the U.S. News College Guide, nearly 70 percent offer an early admissions program." AvERY ET AL., supra note 6, at 1-2.

12. Id. at 2 .
} 
his matriculation upon acceptance, EA permits him to apply to additional colleges in the regular round that follows. ${ }^{13}$ Students bind themselves to the rules of these programs by their attestation to statements in their early-round applications. A look at the language of these statements is instructive of the distinction. Princeton's reads in pertinent part:

If I am offered admission under the Early Decision program, I will matriculate at Princeton in September 2005. I understand that if accepted under Early Decision, I must withdraw all applications (if any) to other institutions and make no new ones. I further acknowledge that it is a violation of the agreement for me to be an Early Decision or Early Action candidate at any other college or university. ${ }^{14}$

Although the ED commitment appears to be contractual in nature, and seemingly satisfies the requirements of offer, acceptance, and consideration, it has been characterized by one expert as merely an "honor-bound agreement" that "doesn't have any legal standing." 15 But, although admits are not contractually bound to matriculate, and no college has ever sued an admitted applicant to compel his matriculation, ${ }^{16}$ perhaps for public relations reasons colleges nevertheless do not suffer breaches of agreement lightly. ${ }^{17}$ In the end, the overwhelming majority of students manifest their honor by indeed matriculating. ${ }^{18}$ According to a 1997 National Association for College Admissions Counseling (NACAC) study, an average of $91.7 \%$ of ED admits matriculated at their ED college. ${ }^{19}$

ED programs at individual colleges suffer from many troublesome aspects, not the least of which are possible constitutional infirmities whose exploration is simply beyond the scope of this Note. The abridgement of choice between would-be competing offers of acceptance that these programs effect is one such troublesome aspect. What renders this abridgement of

13. Id. at 2 .

14. Princeton University Application for Admission to Freshman Class Entering September 2005, at http://www.princeton.edu/pr/admissions/u/appl/pdf/puqppl.pdf (last visited Feb. 10, 2005) (emphasis added).

15. Dan Rosenheck, Harvard May Ignore Early Decision, The HARVARd Crimson, June 6, 2002, available at $\mathrm{http} / /$ www.thecrimson.com/article.aspv?ref=214992 (last visited Feb. 10, 2005) (quoting Martin A. Wilder, Vice President for Admission, Counseling, and Enrollment Practices at the National Association for College Admissions Counseling).

16. "[S]tudents who break the commitment are rarely, if ever, sued or otherwise challenged by the college." Patrick Healy, Harvard Plans To Sidestep Early Admission Restriction, Boston Globe, June 7, 2002 , at A1.

17. See Avery et AL., supra note 6, at 57 (describing retaliatory tactics taken by colleges in response to breaches).

18. Id. at 55; National Association for College Admissions Counseling, Early Decision/Early Action Summary Report (1997).

19. AVERY ET AL., supra note 6, at 55. 
choice troublesome is that it permits a sort of price fixing at above-market levels: the applicant, after all, commits himself to matriculate before he ever receives his financial aid package from the college. In National Society of Professional Engineers $v$. United States, ${ }^{20}$ a group of engineers agreed by an ethics rule to refuse to negotiate or even discuss fees until a potential client had committed to an engineer. ${ }^{21}$ The Supreme Court invalidated the agreement as unreasonably anticompetitive. ${ }^{22}$ The analogy to Professional Engineers is particularly apt because colleges, like the engineers at issue, line up commitments before issuing financial aid packages, and they respect each other's commitments by declining to compete for them.

With the legality of early admissions programs at issue, at least among consulted scholars, it is surprising that these scholars have spilled so little ink on the topic in books and law reviews. After all, it is not as if the stakes are so small as to be negligible. Admission and matriculation to an elite college has long been perceived as the ticket to a successful future, and some evidence bears out the perception. ${ }^{23}$ And, as it stands, tens of thousands of these tickets are being issued annually through early admissions programs. ${ }^{24}$ It is my intention in this Note to fill the void in scholarship by taking up and exploring the legality of these programs under the antitrust rubric that has evolved through numerous Supreme Court decisions over the course of the twentieth century. Because of the dearth of case law and scholarship directly on point, much of my reasoning must necessarily be made by analogy to the facts of already decided cases. Moreover, much of it will also necessarily be speculative, given the way that court composition and machinations have determined the balance of values and thus the outcomes of cases in recent decades. ${ }^{25}$ I hope to demonstrate, ultimately, that early admissions programs are illegal for restraining trade both by fixing prices and by dividing the college admissions market, according to Section 1 of the Sherman Act and its associated Supreme Court jurisprudence.

20. Nat'l Soc'y of Prof'l Eng'rs v. United States, 435 U.S. 679 (1978).

21. Id. at $682-83$.

22. See id. at 693-96.

23. Consider that Yale University has produced four of the past six U.S. Presidents: Presidents Gerald Ford and Bill Clinton (Yale Law School), and Presidents George H.W. and George W. Bush (Yale College).

24. This is the author's estimation.

25. See Gavil ET AL., supra note 1, at 114-17 (recounting the fascinating story of how the dissent became the majority opinion in Arizona v. Maricopa County Medical Society, 457 U.S. 332 (1982), thanks to efforts to control overreaching). 


\section{The Sherman Act and its Associated Jurisprudence}

Because antitrust law is a creature, indeed a creation, of statute, an analysis of the legality of college early admissions programs must logically begin with the Sherman Act of 1890, the nation's first federal antitrust statute. ${ }^{26}$ At a scant two sentences, the first section of the act offers precious little guidance on so broad a topic, and what little it offers is hopelessly broad. It declares to be illegal "[e]very contract, combination in the form of trust or otherwise, or conspiracy, in restraint of trade or commerce ...."27 As courts have repeatedly noted, to read the statute plainly would sweep up too many contracts, combinations, and conspiracies that restrain commerce but ultimately promote competition. Justice Brandeis famously insisted in an early case that "the legality of an agreement or regulation cannot be determined by so simple a test, as whether it restrains competition. Every agreement concerning trade, every regulation of trade, restrains. To bind, to restrain, is of their very essence." 28 Instead, the legality should be determined by a so-called rule of reason, an antitrust doctrine that has acquired such gravity over the years as to now command capitalization in the text of some judicial decisions. ${ }^{29}$ Under a rule of reason analysis, a court considers the purpose, nature, and effects of a restraint, among other factors, to get at its reasonableness in light of the goal of competition. ${ }^{30}$

However, it soon became apparent to courts that certain types of restraints were so strongly productive of anticompetitive effects that to launch inquiries into or entertain arguments about their reasonableness would be wasteful of judicial resources. Among these types are price fixing, in its various forms, ${ }^{31}$ and market division. ${ }^{32}$ The per se rule presumes illegality and denies any opportunity for defendants' rebuttal.

\footnotetext{
26. Id. at 81 ; see also 15 U.S.C. $\S 1$ (2000).

27. 15 U.S.C. $\S 1$.

28. Bd. of Trade v. United States, 246 U.S. 231, 238 (1918).

29. See, e.g., NCAA v. Bd. of Regents, 468 U.S. 85, 103 (1984). The court accords no such respect to the per se standard, although it does recognize the phrase's foreign origin by italicizing it. See id.

30. See Bd. of Trade, 246 U.S. at 239-41.

31. "Under the Sherman Act a combination formed for the purpose and with the effect of raising, depressing, fixing, pegging, or stabilizing the price of a commodity in interstate or foreign commerce is illegal per se." United States v. Socony-Vacuum Oil Co., 310 U.S. 150, 223 (1940).

32. "One of the classic examples of a per se violation of $\S 1$ [of the Sherman Act] is an agreement between competitors at the same level of the market structure to allocate territories in order to minimize competition.” United States v. Topco Assocs., Inc., 405 U.S. 596, 608 (1972).
} 
For several decades, the rule of reason and the per se rule coexisted as the two principal standards by which the legality of concerted actions were measured. But, from as early as 1898 , justices have been blurring the bright line between the two, which was never all that bright to begin with. In United States v. Addyston Pipe \& Steel Co. ${ }^{33}$ Justice Taft drew a new line between primary and ancillary restraints on trade, with the former to receive limited rule of reason analysis and the latter to receive limited per se analysis. ${ }^{34}$ Recent years have only further complicated the former dichotomy, with courts adding an abbreviated or truncated rule of reason, an intermediate standard which has, in turn, bifurcated into the quick look to condemn ${ }^{35}$ and the quick look to exonerate. ${ }^{36}$ The one-time bright line, it might be said, has given way to a spectrum.

Thankfully, in 2000, the executive branch provided the clarification that the judicial branch had not when the Federal Trade Commission and the Department of Justice jointly issued their Antitrust Guidelines for Collaborations Among Competitors. ${ }^{37}$ The guidelines synthesize the various standards into a single decision-making rubric that determines whether the government will challenge a particular collaboration. The executive analysis on whether or not to challenge a collaboration proceeds along similar lines as a judicial analysis on whether or not to declare a collaboration illegal.

The appropriate standard of review, whether per se, "full-blown" rule of reason, or something in between, is so critical because it is effectively outcome-determinative for a given collaboration. If the collaboration is characterized as one for price fixing or market division, for example, and the per se standard is applied, a court will find it illegal and order the appropriate remedy, whether criminal sanctions, damages, or something in between. No hearing will be afforded to the defendant on matters as to reasonableness or procompetitive justifications. In this way, antitrust law resembles much of constitutional law, such as the jurisprudence of equal protection, ${ }^{38}$ for which the governing standard of review largely determines the decision in a case. In

33. United States v. Addyston Pipe \& Steel Co., 85 F. 271 (6th Cir. 1898), aff'd, 175 U.S. 211 (1899).

34. " $[\mathrm{N}]$ o conventional restraint of trade can be enforced unless the covenant embodying it is merely ancillary to the main purpose of a lawful contract ...." Id. at 282.

35. Phillip Areeda, The "Rule of Reason" in Antitrust Analysis: General Issues 37-38 (1981), cited with approval in NCAA v. Bd. of Regents, 468 U.S. 85, 109-10 n.39 (1984).

36. Frank H. Easterbrook, The Limits of Antitrust, 63 TEX. L. REv. 1 (1984).

37. Federal Trade Commission \& U.S. Department of Justice, Antitrust Guidelines Collaborations Among Competitors (Apr. 1, 2000), at http://www.ftc.gov/os2000/04/ftcdojguidelines.pdf (last visited Feb. 10, 2005).

38. See U.S. Const. amend. XIV § 1. 
the case of college early admissions programs, the appropriate standard of review is probably per se, but I endeavor to demonstrate that the restraint on trade is unreasonable and thus illegal under even the fullest analysis of reason.

As a final preliminary matter, it is probably prudent to demonstrate that the Sherman Act and its associated jurisprudence in fact apply to the industry of college admissions, if indeed it can be called an industry. ${ }^{39}$ College admissions are not exempt from the law because colleges have non-profit status, because admissions are noncommercial in nature, or because financial aid represents mere charity or philanthropy. The Supreme Court in NCAA ended all debate as to the defense of non-profit status when it stated flatly: "There is no doubt that the sweeping language of Section 1 applies to nonprofit entities." ${ }^{\prime 0}$ The Third Circuit in Brown University did the same for the defense of noncommercial conduct when it stated that "the payment of tuition in return for educational services constitutes commerce." ${ }^{\prime 41}$ Indeed, it reinforced the statement when it identified the nature of the activity as "plainly commercial." ${ }^{42}$ As to the defense that financial aid is mere charity, the Brown University court replied that it really constitutes a discount, not a gift, and, in any event, cannot be charity if it buys a university the benefits of a stronger student body "with the concomitant institutional prestige." 43

Nevertheless, the nature of college admissions may have some bearing at least on the standard of review to be applied, if not to the prior applicability of the Sherman Act. Again, in Brown, the court indicated that the "nature of higher education, and the asserted procompetitive and pro-consumer features of the Overlap, convince us that a full rule of reason analysis is in order here." 44 It is impossible to say how much weight the court accorded, respectively, to the nature of higher education and the asserted redeeming features, but it seems that the former has at least some importance. Yet, in $N C A A,{ }^{45}$ and again in Arizona v. Maricopa County Medical Society, ${ }^{46}$ the

39. "Colleges have no magical immunity from federal antitrust laws." Ian Ayres, Colleges in Collusion, The New Republic, Oct. 16, 1989, at 19.

40. NCAA v. Bd. of Regents, 468 U.S. 85, 100 n.22 (1984) (construing Goldfarb v. Va. State Bar, 421 U.S. 773, 786-87 (1975)).

41. United States v. Brown Univ., 5 F.3d 658, 666 (3d Cir. 1993).

42. See id. at 667 n.7.

43. Id. at 666-67.

44. Id. at 678 .

45. "[W]e have decided that it would be inappropriate to apply a per se rule to this case. This decision is not based on a lack of judicial experience with this type of arrangement . . . or on our respect for the NCAA's historic role ...." Id. at 100-01.

46. "We are ... unpersuaded by the argument that we should not apply the per se rule in this case because the judiciary has little antitrust experience in the health care industry." Arizona v. Maricopa County Med. Soc'y, 457 U.S. 332, 349 (1982). 
Supreme Court rejected requests that a particular industry or profession be treated deferentially because of a respect for its roles or because of an acknowledged unfamiliarity with its practices. Long before, in the foundational case United States v. Socony-Vacuum Oil Co. ${ }^{47}$ the Court insisted that "the Sherman Act, so far as price-fixing agreements are concerned, establishes one uniform rule applicable to all industries alike." ${ }^{48}$ In any event, whatever the appropriate standard of review is, it seems uncontested that the Sherman Act and the jurisprudence of antitrust law apply in the first place to college admissions. The point seemed to be implicitly conceded by Yale University President Richard Levin when he sought an antitrust exemption from the Department of Justice in 2002 for a collaboration among elite colleges to drop early admission programs. ${ }^{49}$

\section{PER SE ANalysis}

By its terms, Section 1 of the Sherman Act posits two statutory elements to a restraint of trade offense: a concerted action and an anticompetitive effect. Even under a per se standard, then, a plaintiff bringing an antitrust action against colleges practicing early admissions programs must demonstrate the existence of a concerted action. The agreement need not be explicit, but may be implied or inferred from the circumstances. Indeed, one can imagine the practical difficulties if such a requirement were to exist: collaborators could restrain trade with impunity by simply declining to memorialize their concerted actions in writing. Surely, many such actions go unrecorded even without the requirement, as parties understandably tend to be cautious about drafting documents that could turn into tailor-made exhibits for the plaintiff or prosecution in an antitrust action. ${ }^{50}$

The agreements that exist among colleges not to compete for students admitted under binding ED which do damage to other institutions are implicit ones. ${ }^{51}$ They are enforced by the exchange between colleges of lists of

47. United States v. Socony-Vacuum Oil Co., 310 U.S. 150 (1940).

48. Id. at 222 .

49. Daniel Golden, Bill Would Make Colleges Report Legacies, Early Admissions, Wall St. J., Oct. 29, 2003, at B1.

50. See, e.g., JTC Petroleum Co. v. Piasa Motor Fuels, Inc., 190 F.3d 775, 777 (7th Cir. 1999) (inferring the existence of an anticompetitive agreement from conditions "ripe for effective collusion" and certain indirect evidence).

51. AVERy ET AL., supra note 6, at 55. Another writer refers to a "tacit understanding" among the colleges. Jenna Russell, Harvard Won't Take Freshmen Pledged to Other Schools, Boston GloBE, July 20, 2002, at B3. 
students whom they admitted early, ${ }^{52}$ a practice characterized as "reciprocity for self-protection" ${ }^{53}$ by the authors of The Early Admissions Game. ${ }^{54}$ Of course, because colleges already expect their admits to withdraw all other applications and make no new ones upon their ED admission, ${ }^{55}$ the exchange of lists is really superfluous, and reveals a fundamental distrust among colleges as to the likelihood of success without additional enforcement.

Yet, there are also two explicit agreements to which large numbers of colleges have committed themselves: the guidelines of NACAC and the College Board. NACAC's "Definitions of Admission Decision Options" provide that "[t]he Early Decision application supersedes all other applications. Immediately upon acceptance of an offer of admission, a student must withdraw all other applications and make no other applications. ${ }^{157}$ The College Board's "Early Decision Plan Agreement"s8 also directs the behavior of applicants, while holding colleges to more or less procedural guidelines concerning dates for the disbursement of decisions and financial aid packages. Neither set of guidelines requires subscribing colleges to share lists as a means of enforcement, but each commits the colleges to a fundamental agreement as to the binding nature of ED decisions.

In recent years, individual colleges have flouted the NACAC guidelines, and yet escaped punishment. Brown, Princeton, ${ }^{59}$ Harvard, Stanford, and Yale $^{60}$ Universities all derogate from the principle that in addition to a single ED application, an applicant "may apply to other institutions without restriction." ${ }^{\prime 61}$ These colleges nevertheless continue to respect as binding the commitments of early admits to their respective colleges by declining to

52. See Michele Hernandez, A Is for Admission: The Insider's Guide to Getting Into the Ivy League And Other Top Colleges 218 (1997) (explaining the practice at Dartmouth College of mailing a list of finaldecisions to the Ivies and several other highly selective colleges, who routinely remove those students from their own applicant pools).

53. AVERY ET AL., supra note 6, at 55.

54. Id.

55. See Princeton University Application for Admission, supra note 14.

56. National Association for College Admissions Counseling, Definitions of Admission Decision Options in Higher Education, at http://www.nacac.com/downloads/policy_admission_options.pdf (last visited Feb. 10, 2005) [hereinafter NACAC].

57. $I d$.

58. The College Board, The College Board Handbook, 2001, at 1903 (2000).

59. See Tomas Garcia, Brown, Princeton Breach Early Admissions Pact, Yale Daily News, Oct. 4, 2002, at http://www.yaledailynews.com/article.asp?AID=19950 (last visited Feb. 8, 2005).

60. See Bridget Kelly, EA Policy Violates NACAC Compact, Yale Daily News, Nov. 20, 2002, at http://www.yaledailynews.com/article.asp?AID=20925 (last visited Feb. 8, 2005); Bridget Kelly, Harvard Changes Early Admissions Policy, Yale Daily News, Apr. 14, 2003, at http:// www.yaledailynews.com/article.asp?AID=22580 (last visited Feb. 8, 2005).

61. NACAC, supra note 56. 
entertain applications from the applicants. Harvard nearly single-handedly brought down the system when it disclosed in June 2002 that it would break ranks with its peers and begin considering applications from students who had already accepted binding ED offers from other colleges. ${ }^{62}$ One month later, however, Harvard backed off its words and returned to the fold, citing qualms about admitting students who had "unethically" failed to honor their ED commitments. ${ }^{63}$

Harvard's posturing in the summer of 2002 closely resembled a threatened defection from a cartel. The success of a cartel in fixing prices at above-market levels is contingent upon the conformity of its members with agreed conditions. Defection, or "cheating," is always a threat, because it rewards the defector, at least temporarily, with greater profits. Commonly, the defector need only lower his prices below fixed levels, and all or most pricesensitive consumers will respond by redirecting their business from among other cartel members to him. He more than makes up for his decreased profit margins with his increased quantity. Had Harvard followed through with its announced intention in June 2002 to defect from the agreement among its peers, it would surely have been rewarded, not with greater profits but with a stronger student body and greater institutional prestige. ${ }^{64}$ It could have competed openly, for the first time, for substantial numbers of elite applicants to whom it had no previous access under the agreement. And, given its enormous financial resources ${ }^{65}$ and the prestige that it already rightfully enjoys, it could have successfully "poached"66 many of these previously committed applicants. ${ }^{67}$

62. Healy, supra note 16 , at A1.

63. Russell, supra note 51, at B3.

64. See United States v. Brown Univ., 5 F.3d 658, 666-67 (3d Cir. 1993).

65. As of the last accounting at the time of writing, Harvard's endowment stands at more than $\$ 19$ billion. Jenifer L. Steinhardt, Endowment Soars to \$19.3 Billion High, The Harvard Crimson, Sept. 24, 2003, at http://www.thecrimson.com/articleaspx?ref=348898 (last visited Feb. 8, 2005).

66. Jenna Russell uses this piece of figurative language in her piece for the Boston Globe. Russell, supra note 51. The word "poaching" suggests that, to colleges, competition constitutes a trespass onto their property in students admitted early. But it is not the only language of the big game hunt to make its way into the vernacular of college admissions. There is also the even more colorful "trophy hunting," to describe the practice of an applicant who, having already been admitted to one elite college under a nonbinding Early Action program, nevertheless applies in large numbers to other elite colleges merely to collect coveted acceptance letters like trophies. See James Fallows, The Early Decision Racket, AtLantic Monthly, Sept. 2001, at 45.

67. Indeed, history suggests that Harvard would have successfully "poached" many of these previously committed applicants. Harvard has long boasted the nation's highest Regular Decision "yield" among elite colleges, defined as the percentage of Regular Decision admits who ultimately enroll. This stands as evidence of Harvard's superior competitive position. 
It is worth considering why Harvard, with its superior competitive position, nonetheless elected in the end to abide by the agreement when it stood to reward from defection. The authors of The Early Admissions Game, two of them professors in Harvard's Kennedy School of Government, suggest that "colleges may wish to maintain a climate of cooperation with their ED counterparts, recognizing that their interactions span many realms beyond admissions. ${ }^{\prime 68}$ In doing so, they seem to suggest that colleges might engage in retaliatory tactics if a peer fails to maintain this climate of cooperation. At the very least, the colleges could make life more difficult for that peer. Retaliatory sanctions are a principal, hallmark means of enforcement of agreement among cartel members. They would not, moreover, be new to the college admissions industry. As the court in Brown University noted of the Ivy Overlap Group members, all "understood that failing to comply with the Overlap Agreement would result in retaliatory sanctions. Consequently, noncompliance was rare and quickly remedied." Yet, the only "sanctions" the court specifically identified was "a series of complaints" leading to termination of conduct. ${ }^{70}$ The authors of The EA Game claim that NACAC and the College Board "exert influence" over their members to uphold the agreement among colleges. ${ }^{71}$ But, the open violation of particular guidelines by five prominent universities in recent years appears to belie any claim of enforcement power. ${ }^{72}$ Indeed, the association guidelines seem rather toothless in the face of such flouting. Yet, whatever its means of enforcement actually are, and whatever their efficacy actually is, it should be clear enough that some agreement exists, preliminarily. It is an agreement, moreover, both implicit and explicit in nature.

In addition to a concerted action, though, a plaintiff must also demonstrate an anticompetitive effect to prevail in an antitrust action against colleges practicing early admissions programs. ${ }^{73}$ Yet, if the concerted action falls into a recognized per se category, like price fixing or market division, ${ }^{74}$ an anticompetitive effect is irrebuttably presumed under the per se rule, ${ }^{75}$ and the action is declared illegal. Price fixing has been defined broadly by the Supreme Court, at least since United States v. Socony-Vacuum Oil Co.: "Under the Sherman Act a combination formed for the purpose and with the

68. AVERY ET AL., supra note 6, at 56.

69. United States v. Brown Univ., 5 F.3d 658, 663 (3d Cir. 1993).

70. Id.

71. AVERY ET AL., supra note 6, at 56.

72. See NACAC, supra note 56; The College BoARd, supra note 58.

73. See 15 U.S.C. $\$ 1$ (2000).

74. See supra notes 29-30 and accompanying text.

75. GAVIL ET AL., supra note 1, at 95. 
effect of raising, depressing, fixing, pegging, or stabilizing the price of a commodity . . . is illegal per se." ${ }^{, 76}$ Forty years later, the Court reiterated Socony's insistence that "the machinery employed by a combination for pricefixing is immaterial." 77 The machinery employed by the combination of colleges practicing early admissions programs is an effective ban on competitive bidding through financial aid that is strongly analogous to the ban that the Supreme Court struck down as a facial restraint of trade in Professional Engineers. ${ }^{78}$

Financial aid is a major means by which elite colleges compete for top students. A cursory review of college websites reveals that elite colleges charge substantially similar "sticker prices" for tuition, room, board, and fees, regardless of their setting. Yet, they discount these prices for the majority of students by means of financial aid, at the added expense of tens of millions of dollars to their annual operating budgets. America's best value, according to U.S. News \& World Report, is the California Institute of Technology, which provides grants to $58 \%$ of its students, for an average discount of $66 \%$ off full price. ${ }^{79}$ Financial aid thus operates to reduce the price that matters for the purposes of antitrust inquiries: the price that consumers actually pay. Competition among colleges for common admits naturally compels greater financial aid packages and thus lower prices. In fact, it is common practice for admits to submit the package offered by a more generous college to a less generous one, which then may match the offer, just as a grocer matches a competitor's advertised price. ED programs preclude this possibility by limiting admits, take-it-or-leave-it, to the financial aid packages offered by their colleges. Facing no competition from market peers, these colleges enjoy the equivalent of exclusive bargaining rights. They are free, and safe, in offering less-generous financial aid packages than they would on the open market. Indeed, they have every incentive to do just so, as rational maximizers of their own utilities.

The foregone opportunity to negotiate for financial aid that ED entails leads many financial aid candidates to forestall application until the regular round. As a result, ED pools tend to include disproportionate numbers of students able to pay full sticker prices. ${ }^{80}$ This gives colleges additional reason

\footnotetext{
76. United States v. Socony-Vacuum Oil Co., 310 U.S. 150, 223 (1940).

77. Catalano, Inc. v. Target Sales, Inc., 446 U.S. 643, 647 (1980) (citation omitted).

78. Nat'l Soc'y of Prof'l Eng'rs v. United States, 435 U.S. 679 (1978).

79. Best Values: National Universities, U.S. News \& World Report (2005), at http:// www.usnews.com/usnews/edu/college/rankings/brief/bestvalues/bvnatudoc_brief.php (last visited Feb.10, 2005).

80. AVERY ET AL., supra note 6, at 13.
} 
to prefer ED applicants. Charles Deacon of Georgetown characterizes ED as "a programmatic way of rationing your financial aid. First, the ED pool is more affluent, so you spend less money . . . enrolling your class. And then there is absolutely no need to compete on financial packages." ${ }^{\prime 1}$ All told, ED prevents competitive "bidding wars" even better than the mechanisms of the Ivy Overlap Group. In 1986, Princeton provided some temporary competition among group members by introducing merit-based research grants in addition to financial aid. ${ }^{82}$ But, despite Harvard's recent posturing, no college has yet broken ranks to compete financially for another school's early admit. It is therefore apparent that the current agreement constitutes a variety of price fixing that is even more anticompetitive in degree than that achieved under the Overlap Agreement.

\section{Full Rule of Reason Analysis}

Under a per se standard, a court would deem both the Overlap agreement and the agreement among colleges on early admissions as illegal, entertaining no arguments about counterbalancing, pro-competitive justifications. The district court in Brown University, however, declined to apply a per se rule. Instead, "in the exercise of caution" and in deference to the nature of defendants as a professional association of sorts, the court gave a quick look to any pro-competitive defenses. ${ }^{83}$ But, the deference to professional associations is not absolute ${ }^{84}$ and is based, in any event, on their deviation from the usual profit-maximizing economic model. ${ }^{85}$ Judge Richard Posner disputes the qualification of universities for this deference when he writes that "increasingly the outlook of universities in the United States is indistinguishable from that of business firms." ${ }^{966}$ Also deferring to the professional nature of colleges, the circuit court demanded that a full rule of reason analysis be applied to the Overlap Agreement. ${ }^{87}$ Assuming, arguendo, that full rule of reason is in fact appropriate, the agreement among colleges to respect each other's ED commitments should still be deemed illegal.

Many justifications can be and have been offered in support of ED programs. One could argue, for example, that "locking in" a large fraction of

\footnotetext{
81. Fallows, supra note 66 , at 46.

82. United States v. Brown Univ., 5 F.3d 658, 663 (3d Cir. 1993).

83. United States v. Brown Univ., 805 F. Supp. 288, 301 (E.D. Pa. 1992).

84. See Arizona v. Maricopa County Med. Soc'y, 457 U.S. 332, 332-33 (1982).

85. Nat'l Soc'y of Prof'l Eng'rs v. United States, 435 U.S. 679, 696 (1978).

86. Richard A. Posner, The University as Business, Atlantic Monthly, June 2002, at 21.

87. Brown Univ., 5 F.3d at 672.
} 
its class early facilitates a college to craft a class with a desirable demographic profile, or that it gives early peace of mind to admitted students. Of course, the benefits accrue disproportionately to the colleges, so much so that Yale President Richard Levin suggests that the only party who benefits is the admissions officers. ${ }^{88}$ And, crucially, the benefits are not pro-competitive. Two of MIT's proffered pro-competitive justifications in Brown University turned upon the improved socio-economic diversity made possible by the Overlap Agreement, with its conservation of financial aid resources for disbursement to the most needy. ${ }^{89}$ Colleges are unlikely to overcome their burden on parallel arguments here, as minorities and financial aid candidates tend not to apply early. ${ }^{90}$ MIT's third justification, that reduced price competition frees colleges to compete on measures such as faculty and facility quality, is likewise unlikely to work in this situation, as the circuit court notes that "any competition that survives a horizontal price restraint naturally will focus on attributes other than price. This is not the kind of procompetitive virtue contemplated under the [Sherman] Act, but rather one mere consequence of limiting price competition." ${ }^{\prime 1}$ Rather than increasing competition, then, the agreement merely shifts its ground. In any event, the plaintiff in any suit against colleges could shift back the burden to the colleges by showing that less-restrictive means for achieving these or other procompetitive goals exist. The point is moot, though, in the absence of any viable, pro-competitive justifications.

One can imagine colleges defending themselves on the ground that ED programs decrease competition consensually, with the compliance of applicants who voluntarily forego the opportunity to weigh offers and to negotiate financial aid packages. The Supreme Court rebuffed such a defense in Professional Engineers, holding price comparison in the initial selection of engineers to be crucial. ${ }^{92}$ Apparently, if price information were made available to them beforehand, prospective consumers of engineering services could commit themselves to particular engineers and thereby forego negotiation of bids, without the Sherman Act being implicated. But, the denial of this information until after selection is made unreasonably commits consumers to the whims of engineers, who set their prices in the absence of competitive pricing pressures. By this logic, colleges offering ED programs

88. Karen W. Arenson, Yale President Wants To End Early Decisions for Admissions, N.Y. Times, Dec. 13, 2001, at D1.

89. Brown Univ., 5 F.3d at 674-75.

90. AVERY ET AL., supra note 6, at 136.

91. Brown Univ., 5 F.3d at 675.

92. Nat'l Soc'y of Prof'1 Eng'rs v. United States, 435 U.S. 679, 692 (1978). 
could shore up their legal vulnerabilities in part by providing accurate financial aid estimation in advance of application. Princeton has done just this with its Early Estimator for Financial Aid, an online calculator which provides "not a commitment of an aid award" but "a reasonable approximation of possible aid." ${ }^{93}$ Assuming the Estimator to be accurate, Princeton's ED program can hardly be characterized as anticompetitive. It becomes analogous to most products or services, which are bought on the basis of prior pricing information.

\section{CONCLUSION}

Pricing, by way of financial aid calculation, must be made at a stage where competition exists. Colleges should either offer individual estimations of financial aid prior to application, or they should permit open-market negotiation of financial aid after application and admission. If they are unwilling to do the former, they remain open targets for an antitrust lawsuit. In a footnote, the authors of The Early Admissions Game speculate about this possibility: "It is conceivable that courts would find the sharing of lists of accepted ED applicants to be collusive and illegal. There have been no court cases on this matter, and the legal scholars we consulted disagreed about the legality of the practice." ${ }^{94}$ Noting the absence of such cases, the 2001 Time/Princeton Review College Guide went so far as to suggest a class-action suit against colleges that practice early admissions programs. ${ }^{95}$ Likewise, the FTC-DOJ Antitrust Guidelines would seem to recommend a challenge by the United States in criminal court. Under any standard of review, from per se to full rule of reason, a court should find the agreement currently in place among colleges, mutually enforcing Early Decision commitments, to be an illegal restraint of trade under the Sherman Act.

93. Early Estimator for Financial Aid at Princeton, at http://www.princeton.edu/pr/aid/estim.shtml (last visited Feb. 10, 2005).

94. AVERY ET AL., supra note 6, at 335 n.27.

95. Id. at 82 . 